\title{
ANALISIS EKONOMI USAHA TERNAK BABI DENGAN PEMBERIAN SEKAM PADI DALAM RANSUM YANG MENGANDUNG LIMBAH HOTEL
}

\author{
ARIANA I.N.T., PUGER A.W., OKA A.A., SRIYANI N.L.P \\ Fakultas Peternakan, Universitas Udayana, Jl. P.B. Sudirman, Denpasar, Bali. \\ Email:ariana_gapar@yahoo.co.id
}

\begin{abstract}
ABSTRAK
Penelitian ini bertujuan untuk mengetahui pengaruh penggunaan sekam padi sebagai sumber serat dalam ransum yang mengandung limbah hotel terhadap analisis ekonomi usaha ternak babi. Dua puluh empat ekor babi

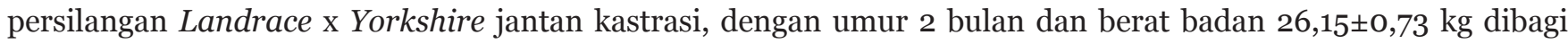
dalam empat perlakuan ransum, yaitu tanpa sekam padi (Ro), 10\% sekam padi (R1), 20\% sekam padi (R2), dan 30\% sekam padi (R3), masing-masing terdiri atas enam ekor ternak babi. Penelitian menggunakan kandang individu berukuran panjang 1,9 m dan lebar 0,5 m. Pakan diberikan secara ad libitum. Penelitian menggunakan Rancangan Acak Lengkap (RAL) pola searah. Data yang diperoleh dianalisis dengan one-way ANOVA. Apabila terdapat perbedaan, analisis dilanjutkan dengan menggunakan Duncan's New Multiple Range Test (DMRT). Hasil penelitian menunjukkan bahwa total biaya konsumsi, biaya konsumsi ransum harian, biaya ransum per kilogram

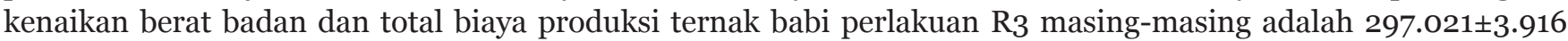
rupiah/ekor, 4.243 $\pm 55 \mathrm{rupiah} / \mathrm{ekor} / \mathrm{hari}, 5.132 \pm 314 \mathrm{rupiah} / \mathrm{kg}$ dan 627.021 $\pm 3.916 \mathrm{rupiah} / \mathrm{ekor}$, dan ini lebih rendah $(\mathrm{P}<0,05)$ daripada perlakuan Ro dan R1 yang masing-masing adalah 406.908 \pm 14.529 dan 400.480 \pm 17.819

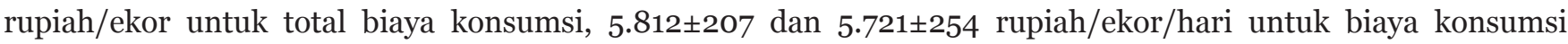
ransum harian, $6.314 \pm 433$ dan $5.822 \pm 119$ rupiah/kg untuk biaya ransum per kilogram kenaikan berat badan serta $736.908 \pm 14.529$ dan $730.480 \pm 17.819$ rupiah/ekor untuk total biaya produksi. Total pendapatan pada perlakuan R1yaitu 963.666 \pm 54.701 rupiah/ekor, lebih tinggi $(\mathrm{P}<0,05)$ daripada perlakuan $\mathrm{R} 2$ dan $\mathrm{R} 3$ yang masing-masing hanya $837.666 \pm 79.894$ dan $813.166 \pm 59.465$ rupiah/ekor. Keuntungan usaha, income over feed cost dan B/C rasio usaha ternak babi diantara keempat perlakuan berbeda tidak nyata. Disimpulkan bahwa penggunaan sekam padi pada level 10\% dalam ransum yang mengandunglimbah hotel lebih menguntungkan.
\end{abstract}

Kata kunci: Sekam padi, Limbah hotel, Analisis ekonomi, Babi

\section{AN ECONOMIC ANALYSIS OF PIGS FED RICE HULLS IN THE DIET WITH CONTAINING HOTEL FOOD WASTE}

\begin{abstract}
The aim of study was to observe the effect of rice hull as a fibre source in the pig's diet with containing hotel food waste on the economic analysis. Twenty four heads of 2 month old and $26.15 \pm 0.73 \mathrm{~kg}$ initial body weight Landrace $\mathrm{x}$ Yorkshire cross barrow were randomly divided into four treatment groups, as of without rice hull (Ro), $10 \%$ rice hull (R1), 20\% rice hull (R2), and 30\% rice hull (R3), each group consisted of six individual pigs. The study was used individual pen with $1.9 \mathrm{~m}$ in length and $0.5 \mathrm{~m}$ in width. Feed was give as ad libitum. The obtained data were analyze using one-way ANOVA, and continued using Duncan's new Multiple Range Test (DMRT) for significant differences. The results of this study showed that the total of feed cost, daily feed cost, feed cost per kilogram of weight gain and total production cost of $\mathrm{R} 3$, which were 297,021 $\pm 3,916 \mathrm{rupiah} / \mathrm{head}, 4,243 \pm 55 \mathrm{rupiah} / \mathrm{head} / \mathrm{day}$, $5,132 \pm 314 \mathrm{rupiah} / \mathrm{kg}$ and 627,021 $\pm 3,916 \mathrm{rupiah} / \mathrm{head}$, respectively, and lower $((\mathrm{P}<0.05)$ than in Ro and R1, which

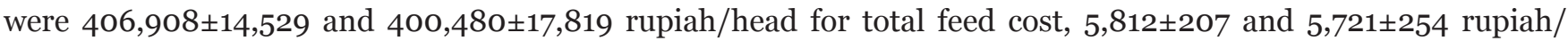
head/day for daily feed cost, $6,314 \pm 433$ and 5,822 \pm 119 rupiah/kg for feed cost per kilogram of weight gain and also $736,908 \pm 14,529$ and $730,480 \pm 17,819$ rupiah/head for total production cost. Total revenue was higher $(\mathrm{P}<0.05)$ in $\mathrm{R} 1$, which was 963,666 $\pm 54,701 \mathrm{rupiah} / \mathrm{head}$, than in R2 and R3, which were 837,666 $\pm 79,894$ and 813,166 $\pm 59,465$ rupiah/head, respectively. Total benefit, income over feed cost and B/C ratio among the four different groups were not significant differences. It was concluded that the use of $10 \%$ rice hull in the diet with containing hotel food waste was more profitable.
\end{abstract}

Key words: Rice hull, Hotel food waste, Economic analysis, Pigs 


\section{PENDAHULUAN}

Pengembangan peternakan babi dapat menjadi potensi yang baik dalam membuka peluang usaha dan lapangan pekerjaan. Data Dirjen Peternakan (2012) menunjukkan bahwa populasi ternak babi di Indonesia tahun 2011 berada pada kisaran 7.524.788 ekor, lebih rendah daripada populasi kambing yang berjumlah 16.946.187 ekor dan domba yang berjumlah 11.790.612 ekor. Hal ini menunjukkan bahwa perkembangan perternakan babi di Indonesia masih belum maksimal dibandingkan dengan negara sedang berkembang lainnya seperti Vietnam, Thailand dan Filipina.

Produksi ternak babi selain diarahkan untuk menghasilkan daging dengan kualitas yang baik, juga diupayakan untuk menekan biaya produksi yang tinggi. Pakan merupakan faktor biaya produksi tertinggi yaitu sekitar $55-85 \%$ dari total biaya produksi. Limbah hotel merupakan salah satu bahan pakan hasil sisa industri yang memiliki nilai gizi cukup tinggi, sedangkan sekam padi merupakan sumber serat yang sangat melimpah di Indonesia. Menurut Rika et al. (1995), produksi limbah dari 55 hotel berbintang di Bali sebanyak 1,97 ton DM/hari. Jumlah limbah hotel dan sekam padi yang melimpah dan pemanfaatannya yang masih sangat rendah menyebabkan harga bahan pakan tersebut sangat murah.

Limbah hotel memiliki kelemahan seperti lemak kasar dan kadar air yang tinggi, serta serat kasar yang rendah. Bidura et al. (2008) menyatakan bahwa kandungan lemak kasar dalam limbah hotel yaitu 18,4123,92\%. Pemberian ransum yang mengandung limbah hotel menyebabkan peningkatan persentase lemak karkas dan menurunkan persentase daging babi. Harris (2002) menyatakan bahwa standar lemak karkas babi yang direkomendasikan USDA adalah 19-20\%.

Mengantisipasi permasalahan di atas, maka pemberian limbah hotel perlu diimbangi dengan penambahan serat berupa sekam padi untuk mengurangi pengaruh lemak dalam limbah hotel. Budaarsa (1997) melaporkan bahwa penggunaan sekam padi hingga level 10\% dalam ransum babi yang mengandung 10\% lemak tallow secara nyata meningkatkan pertumbuhan ternak babi. Peningkatan pertumbuhan akan menyebabkan peningkatan nilai tambah ternak pada saat dijual. Penelitian lain yang dilaporkan oleh Shriver et al. (2003) mendapatkan bahwa pemberian sekam kedelai dalam ransum babi berpengaruh tidak nyata terhadap pertumbuhan ternak. Hal ini menunjukkan bahwa pemanfaatan bahan pakan murah pada level yang tepat akan memberikan keuntungan ekonomi. Penelitian dilaksanakan untuk mengetahui pengaruh penggunaan sekam padi sebagai sumber serat dalam ransum yang mengandung limbah hotel terhadap analisis ekonomi usaha ternak babi.

\section{Materi dan Metode}

Penelitian menggunakan 24 ekor babi persilangan Landrace x Yorkshire jantan kastrasi, umur 2 bulan dengan berat badan $26,15 \pm 0,73 \mathrm{~kg}$. Kandang yang digunakan adalah kandang individu berukuran panjang 1,9 m, dan lebar 0,5 m. Penelitian menggunakan empat perlakuan level sekam padi dalam ransum yaitu ransum tanpa sekam padi (Ro), ransum mengandung 10\% sekam padi (R1), ransum mengandung $20 \%$ sekam padi (R2) dan ransum mengandung 30\% sekam padi (R3), masing-masing terdiri atas enam ekor ternak.

Bahan pakan yang digunakan terdiri dari tepung jagung, tepung ikan, pollard, bungkil kelapa dan limbah hotel sebagai bahan pakan utama, serta sekam padi sebagai bahan pakan perlakuan. Prosedur pengolahan limbah hotel dilakukan menurut metode Westendorf et al. (1998) yang meliputi tahapan penyortiran dan perebusan, sedangkan tahapan pengeringan, penggilingan dan penyimpanan dilakukan menurut metode Yanis et al. (2000). Sekam padi yang digunakan berasal dari padi jenis serang yang digiling menggunakan mesin merk Honda GX 160 dilengkapi saringan berdiameter lubang $1 \mathrm{~mm}$. Seluruh bahan pakan dianalisis kandungan nutriennya. Kandungan nutrien ransum disusun berdasarkan rekomendasi NRC (1998) serta Kyriazakis dan Whittemore (2006).

Materi babi sebanyak 24 ekor diidentifikasi dengan pemberian nomor, selanjutnya dilakukan pengacakan tempat dan perlakuan. Ternak babi kemudian diadaptasikan dengan kandang dan pakan selama satu minggu, yang dilanjutkan tahappengamatan selama 10 minggu. Pencampuran ransum dilakukan setiap satu minggu sekali. Ransum diberikan secara ad libitum. Pemberian ransum dilakukan pagi dan sore hari, sedangkan penimbangan sisa ransum dilakukan pada pagi hari berikutnya menggunakan timbangan duduk kapasitas 10 kg (ketelitian $50 \mathrm{~g}$ ). Penimbangan berat badan ternak dilakukan menggunakan timbangan gantung kapasitas $100 \mathrm{~kg}$ (ketelitian $500 \mathrm{~g}$ ).

Variabel yang diamati meliputi total biaya konsumsi yaitu jumlah konsumsi dikalikan harga ransum, biaya ransum per kilogram peningkatan berat badan, total biaya produksi yang meliputi biaya bibit, obat, susut kandang dan susut alat kandang pada nominal yang sama ditambah biaya ransum, total penerimaan yaitu hasil penjualan setiap ekor ternak, keuntungan yaitu selisih antara total penerimaan dengan total biaya produksi, income over feed cost yaitu selisih antara penerimaan dengan biaya konsumsi ransum setiap ekor ternak dan $\mathrm{B} / \mathrm{C}$ rasio yaitu perbandingan antara keuntungan dengan total biaya produksi.

Data yang diperoleh dianalisis dengan one-way ANOVA. Apabila terdapat perbedaan, analisis dilanjutkan dengan menggunakan Duncan's New Multiple 
Range Test (DMRT) (Steel dan Torrie, 1993). Pengolahan data dilakukan dengan menggunakan program SPSS versi 13.0 for windows (SPSS Inc, 2007).

\section{HASIL DAN PEMBAHASAN}

Total biaya konsumsi ransum ternak babi perlakuan $\mathrm{R} 3$ lebih rendah $(\mathrm{P}<0,05)$ daripada ketiga perlakuan lainnya, demikian pula pada perlakuan R2 lebih rendah $(\mathrm{P}<0,05)$ daripada perlakuan Ro dan R1 (Tabel 1). Biaya konsumsi ransum harian ternak babi perlakuan $\mathrm{R} 3$ lebih rendah $(\mathrm{P}<0,05)$ daripada ketiga perlakuan lainnya, demikian pula pada perlakuan R2 lebih rendah $(\mathrm{P}<0,05)$ daripada perlakuan Ro dan R1 (Tabel 1). Rendahnya biaya konsumsi ransum ternak babi pada perlakuan R3 disebabkan karena harga sekam padi yang murah, sehingga dengan pemanfaatan sebanyak $30 \%$ pada perlakuan $\mathrm{R}_{3}$ akan menghasilkan harga ransum yang murah. Jumlah konsumsi ransum harian ternak

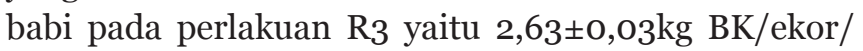
hari yang lebih rendah daripada Ro, R1 dan R2 yang secara berturut-turut adalah 2,66 $\pm 0,86 ; 2,85 \pm 0,12$ dan 2,64 $\pm 0,04 \mathrm{~kg} \mathrm{BK} / \mathrm{ekor} /$ hari juga berakibat pada rendahnya biaya konsumsi ransum ternak babi pada perlakuan R3. Rendahnya konsumsi ransum ternak babi akibat pemberian serat dalam ransum juga pernah dilaporkan oleh Millet et al. (2012) yaitu 1,87 kg BK/ ekor/hari untuk pemberian serat dengan ukuran partikel kecil dan 1,95 kg BK/ekor/hari untuk pemberian serat dengan ukuran partikel sedang.

Biaya ransum per kilogram kenaikan berat badan ternak babi perlakuan $\mathrm{R} 3$ lebih rendah $(\mathrm{P}<0,05)$ daripada perlakuan Ro dan R1, demikian pula pada perlakuan $\mathrm{R} 1$ lebih rendah $(\mathrm{P}<0,05)$ daripada perlakuan Ro (Tabel 1). Harga ransum pada perlakuan $\mathrm{R}_{3}$ yang lebih murah menyebabkan biaya yang dibutuhkan untuk setiap kenaikan berat badan ternak babi menjadi lebih rendah, walaupun FCR ternak babi yang mendapat perlakuan $\mathrm{R} 3$ merupakan yang paling tinggi yaitu 3,18 $\pm 0,20$, lebih tinggi daripada ketiga perlakuan lainnya yang berturut- turut 2,89 $\pm 0,20 ; 2,90 \pm 0,07$ dan 3,10 $\pm 0,25$. Biaya ransum per kilogram kenaikan berat badan ternak babi perlakuan R1 yang lebih rendah daripada ternak babi yang mendapat perlakuan Ro disebabkan karena pertambahan berat badan harian ternak babi pada perlakuan $\mathrm{R} 1$ merupakan yang paling tinggi yaitu $0,98 \pm 0,06 \mathrm{~kg} /$ ekor/hari, lebih tinggi daripada perlakuan Ro, R2 dan R3 yang masing-masing hanya $0,93 \pm 0,08 ; 0,86 \pm 0,08$ dan $0,83 \pm 0,06 \mathrm{~kg} /$ ekor/hari. Penurunan pertambahan berat badan harian ternak babi akibat pemberian serat dalam ransum juga pernah dilaporkan oleh Millet et al. (2012) yaitu $0,771 \mathrm{~kg}$ pada pemberian serat dengan ukuran partikel kecil serta penelitian Shriver et al. (2003) yang mendapatkan pertambahan berat badan $0,77 \mathrm{~kg}$ untuk pemberian serat berupa sekam kedelai dalam ransum.

Total biaya produksi pada perlakuan $\mathrm{R} 3$ lebih rendah $(\mathrm{P}<0,05)$ daripada ketiga perlakuan lainnya, demikian pula pada perlakuan $\mathrm{R} 2$ lebih rendah $(\mathrm{P}<0,05)$ daripada perlakuan Ro dan R1 (Tabel 1). Hal ini disebabkan karena biaya ransum pada perlakuan R2 dan R3 lebih rendah daripada perlakuan Ro dan R1. Biaya ransum merupakan faktor biaya tertinggi dalam usaha ternak babi.

Total pendapatan pada perlakuan R1 lebih tinggi $(\mathrm{P}<0,05)$ daripada perlakuan $\mathrm{R} 2$ dan $\mathrm{R} 3$, demikian pula pada perlakuan Ro lebih tinggi $(\mathrm{P}<0,05)$ daripada perlakuan R3 (Tabel 1). Total pendapatan diperoleh dari hasil penjualan berdasarkan berat badan akhir ternak babi, sehingga tingginya total pendapatan pada ternak babi yang mendapat perlakuan R1 dan Ro disebabkan karena berat badan akhir ternak babi pada perlakuan tersebut yang masing-masing $95,00 \pm 4,37$ dan $90,75 \pm 6,28 \mathrm{~kg}$, lebih tinggi daripada ternak babi yang mendapat perlakuan R2 dan R3 yang masing-masing hanya $86,00 \pm 5,68$ dan $84,33 \pm 4,67 \mathrm{~kg}$. Penurunan berat badan akhir akibat pemberian serat pernah dilaporkan oleh Jin et al. (1994), dan Len et al. (2008).

Keuntungan usaha ternak babi diantara keempat perlakuan berbeda tidak nyata, demikian pula income

Tabel 1. Pengaruh penggunaan sekam padi dalam ransum yang mengandung limbah hotel terhadap analisis ekonomi usaha ternak babi

\begin{tabular}{|c|c|c|c|c|}
\hline \multirow{2}{*}{ Variabel } & \multicolumn{4}{|c|}{ Perlakuan } \\
\hline & RO & R1 & R2 & R3 \\
\hline Biaya konsumsi ransum harian (Rp/ekor/hari) & $5.812 \pm 207^{\mathrm{a}}$ & $5.721 \pm 254^{\mathrm{a}}$ & $4.642 \pm 83^{b}$ & $4.243 \pm 55^{c}$ \\
\hline Total biaya produksi (Rp/ekor) & $736.908 \pm 14.529^{a}$ & $730.480 \pm 17.819^{a}$ & $654.981 \pm 5.805^{b}$ & $627.021 \pm 3.916^{c}$ \\
\hline Total pendapatan (Rp/ekor) & $906.500 \pm 79.288^{\mathrm{ab}}$ & $963.666 \pm 54.701^{\mathrm{a}}$ & $837.666 \pm 79.894^{\mathrm{bc}}$ & $813.166 \pm 59.465^{c}$ \\
\hline Keuntungan (Rp/ekor) & $169.591 \pm 68.290^{\mathrm{a}}$ & $233.185 \pm 38.179^{a}$ & $182.684 \pm 74.431^{\mathrm{a}}$ & $186.145 \pm 55.961^{\mathrm{a}}$ \\
\hline
\end{tabular}

Keterangan:

a,b,c Superskrip yang berbeda pada baris yang sama menunjukkan berbeda nyata

$(P<0,05)$. RO: sekam padi $0 \%$, R1: sekam padi $10 \%, \mathrm{R} 2$ : sekam padi $20 \%, \mathrm{R} 3$ : sekam padi $30 \%$ 
over feed costusaha ternak babi diantara keempat perlakuan berbeda tidak nyata (Tabel 1). Hal ini disebabkan karena penggunaan sekam padi pada level $30 \%$ walaupun mampu menurunkan harga ransum, tetapi belum mampu menghasilkan pertambahan berat badan yang maksimal. Tingkat keuntungan dan income over feed cost pada perlakuan R1 yang paling tinggi yaitu masing-masing $233.185 \pm 38.179$ rupiah/ekor dan $563.185 \pm 38.179$ rupiah/ekor disebabkan karena dengan pemberian $10 \%$ sekam padi dalam ransum yang mengandung 50\% limbah hotel mampu menghasilkan pertumbuhan dan berat badan akhir yang terbaik, sehingga pendapatan yang diperoleh menjadi lebih tinggi.

$\mathrm{B} / \mathrm{C}$ rasio usaha ternak babi diantara keempat perlakuan berbeda tidak nyata (Tabel 1). Hal ini disebabkan karena tingkat keuntungan dan income over feed cost usaha ternak babi yang dihasilkan juga tidak berbeda. Faktor berat badan akhir sebagai penentu total pendapatan hanya dapat dimaksimalkan pada pemberian $10 \%$ sekam padi (R1), sehingga dengan jumlah konsumsi dan harga ransum yang lebih tinggi dari perlakuan R2 dan R3, maka rasio antara keuntungan dan total biaya produksi menjadi tidak maksimal. $\mathrm{B} / \mathrm{C}$ rasio pada perlakuan R1 yang paling tinggi yaitu $0,32 \pm 0,05$ menunjukkan bahwa perlakuan dengan 10\% sekam padi dapat menghasilkan keuntungan maksimal, yaitu untuk setiap Rp. 100,- biaya yang dikeluarkan, maka keuntungan yang akan diterima sebesar Rp. 32,--

Penggunaan sekam padi pada level 10\% dalam ransum yang mengandung 50\% limbah hotel mampu meningkatkan total pendapatan, sedangkan penggunaan sekam padi pada level 30\% mampu menekan biaya konsumsi ransum usaha ternak babi.

\section{DAFTAR PUSTAKA}

Bidura, I. G. N. G., Partama I. B. G. dan Susila T. G. O. 2008. Limbah Pakan Ternak Alternatif dan Aplikasi Teknologi. Udayana University Press. Denpasar, Bali. Pp. 69-72.

Budaarsa, K. 1997. Kajian penggunaan rumput laut dan sekam padi sebagai sumber serat dalam ransum untuk menurunkan lemak karkas dan kolesterol daging babi. Disertasi. Institut Pertanian Bogor, Bogor.
Dirjen Peternakan. 2012. Statistik Peternakan. Available at http://ditjennak.deptan.go.id/index.php?page=statis tik\&action=info\&idcat $=1$. Accessed at June $25^{\text {th }}, 2013$.

Harris, T. G. 2002. Training Manual for USDA Standards for Grading Slaughter Animals: Slaughter Hog Grading. Georgia Agriculture Education Curriculum Office, University of Georgia, Georgia.

Jin, L., Reynolds L. P., Redmer, D. A., Caton, J. S., and Crenshaw, J. D. 1994. Effects of dietary fiber on intestinal growth, cell proliferation, and morphology in growing pigs. J. Anim. Sci. 72: 2270-2278.

Kyriazakis, I. and Whittemore, C. T. 2006. Conclusion. in: Whittemore's Science and Practice of Pig Production. Kyriazakis, I. and C. T. Whittemore (eds). Vol. 3. Blackwell Publishing Ltd. Oxford, UK. Pp. 645-658.

Len, N. T., Lindberg, J. E. and Ogle, B. 2008. Effect of dietary fiber level on the performance and carcass traits of mong cai, F1 crossbred (Mong cai $\times$ Yorkshire) and Landrace $\times$ Yorkshire pigs. Asian-Aust. J. Anim. Sci. 21: 245-251.

Millet, S., Kumar, S., De Boever, J., Meyns, T., Aluwé, M., De Brabander, D. and Ducatelle, R. 2012. Effect of particle size distribution and dietary crude fibre content on growth performance and gastric mucosa integrity of growing-finishing pigs. Vet. J. 192: 316-321.

Noblet, J. and Perez, J. M.. 1993. Prediction of digestibility of nutrients and energy values of pig diets from chemical analysis. J. Anim. Sci. 71: 3389-3398.

NRC. 1998. Nutrient Requirements of Swine (ed). Vol. 10. National Academy Press, Washington, USA. Pp. 110-123.

Rika, I. K.,. Susila, T. G. O, Chandraasih, N. K. dan Redjonta, I. W. 1995. Potensi limbah hotel dalam mendukung usaha peternakan babi di Kabupaten Badung. Laporan Kegiatan Penelitian Kaji Tindak Kerjasama LPM Unud dengan Pemda Tk.II Badung, Bali.

Shriver, J. A.,. Carter, S. D, Sutton, A. L., Richert, B. T., Senne, B. W. and Petty, L. A. 2003. Effects of adding fiber sources to reduced-crude protein, amino acid-supplemented diets on nitrogen excretion, growth performance, and carcass traits of finishing pigs. J. Anim. Sci. 81: 492-502.

SPSS Inc. 2007. SPSS Base 16.0 User's Guide. Available at http://www.spss.com. Accessed at June 25 $5^{\text {th }}, 2013$.

Westendorf, M. L., Dong, Z. C., and Schoknecht, P. A. 1998. Recycled cafetaria food waste as a feed for swine: nutrient content, digestibility, growth, and meat quality. $J$. Anim. Sci. 76: 2976-2983.

Yanis, M., Zainuddin, D., Suryawati, R. W. dan Rochjat, M. D. 2000. Pemanfaatan Limbah Restoran untuk Ransum Ayam Buras. Badan Penelitian dan Pengembangan Pertanian, Jakarta. Pp. 3-5. 